\title{
Brood size of four titmice (Paridae) during 1962-2001
}

\author{
Kullstorlek för fyra arter mesar (Paridae) 1962-2001
}

HANS RYTTMAN \& K. SUSANNA S. HALL-KARLSSON

\begin{abstract}
Breeding success of four titmice breeding in forests was investigated during 1962-2001. Three of them, Coal Tit Parus ater, Willow Tit Parus montanus and Marsh Tit Parus palustris have shown declining population trends in the annual monitoring of bird species in Sweden. The fourth species, the Crested Tit Parus cristatus, has shown a stable population size. Two of the declining species, Marsh Tit and Coal Tit, had the largest broods during the most recent decade and significantly positive trends in brood sizes during the investigated period, whereas the Willow Tit and Crested Tit had stable brood sizes. Our study indicates that the declines of the Coal Tit, Willow Tit and Marsh Tit populations in Sweden cannot be ex-
\end{abstract}

plained by changes in brood size, number of dead nestlings or number of un-hatched eggs. The stable population size of Crested Tit might be explained by its habit of breeding early in the season, which has become more pronounced during the most recent decades, probably in order to match breeding to the earlier spring arrival nowadays.

Hans Ryttman, Skönstaholmsvägen 68, 12360 Farsta. E-mail: hans.ryttman@comhem.se Susanna Hall-Karlsson, Torsten Alms gata 23, 12651 Hägersten.E-mail: susanna.hallkarlsson@gmail.com

Received 29 September 2009, Accepted 24 June 2010, Editor: D. Hasselquist

\section{Introduction}

The bird populations of Sweden have been monitored annually since 1975 (Lindström \& Svensson 2002). In the annual report for 2006 , Lindström \& Svensson (2007) stated that the Willow Tit Parus montanus and the Marsh Tit Parus palustris had declined for the last 25 years, whereas the Coal Tit Parus ater started to decrease in the 1990s and the Crested Tit Parus cristatus showed a stable population.

There are two mutually non-exclusive causes for a decline of a population - lower production of offspring or decreased survival of nestlings or older birds. The optimal brood size of a species depends on several factors such as survival probability of young, life expectancy of adults, habitat favourability and predation pressure. In a stable population, the number of offspring surviving to reproductive age should equal the number of adults dying or dispersing from the population each year.

In this study, we investigate the average brood size and number of ringed broods from 1962 to 2001 for the four titmice species. The aim was to investigate if changes in brood size and the proportion of unhatched eggs and dead nestlings per brood could play a role in the declining populations of the titmice.

\section{Materials and methods}

This study is based on bird ringing data from 1962 to 2001 reported to the Swedish Bird Ringing Centre (Swedish Museum of Natural History). The four species included, Coal Tit, Crested Tit, Willow Tit and Marsh Tit, depend on forest habitats, and their breeding population changes have been estimated in the Annual report of the Swedish bird monitoring for 2006 (Lindström \& Svensson 2007). Altogether, 6447 broods were included in the present study. The total number of broods ringed, the average brood size and the range of brood sizes of each species is presented in Table 1. The term 'brood size' used in this study denotes the number of nestlings alive at the ringing occasion even if not all of them were ringed. Unhatched eggs and dead nestlings were not included in the average brood size, if nothing else is stated. The numbers of unhatched eggs and dead nestlings were analysed separately for 1982-2001 since this data was not regularly reported until 1982. It is not possible from this data to tell how many of the nestlings that were predated or died for other reasons.

The number of nestlings of each species included in this study is not equal to the total number of nestlings of the same species ringed in Sweden. In some broods, not all nestlings were ringed, but they 
Table 1. Species names, total number of broods ringed 1962-2001 (n), average brood size 1962-2001 with standard error (s.e.) in parentheses, and brood size range.

Artnamn, totalt antal kullar ringmärkta 1962-2001 (n), medelantal ungar per kull 1962-2001 med standardfelet (s.e.) inom parentes samt spridning $i$ kullstorlek.

\begin{tabular}{lccc}
\hline & $\mathrm{n}$ & $\begin{array}{c}\text { Average (s.e) } \\
\text { Medel (s.e) }\end{array}$ & $\begin{array}{c}\text { Range } \\
\text { Spridning }\end{array}$ \\
\hline Coal Tit Parus ater Svartmes & & $7.74(0.032)$ & $1-13$ \\
Crested Tit Parus cristatus Tofsmes & 3279 & $4.32(0.055)$ & $1-7\left(9^{*}\right)$ \\
Willow Tit Parus montanus Talltita & 425 & $6.68(0.078)$ & $1-11$ \\
Marsh Tit Parus palustris Entita & 570 & $7.05(0.041)$ & $1-12$ \\
\hline Sum Summa & 2173 & &
\end{tabular}

Sum Summa

6447

*Only one brood of this size. Endast en kull med denna storlek.

Table 2. Number of ringed broods per decade 1962-2001.

Antal ringmärkta kullar per årtionde under 1962-2001.

\begin{tabular}{lcccc}
\hline & $1962-1971$ & $1972-1981$ & $1982-1991$ & $1992-2001$ \\
\hline Coal Tit Svartmes & 440 & 796 & 1184 & 859 \\
Crested Tit Tofsmes & 121 & 216 & 54 & 34 \\
Willow Tit Talltita & 98 & 257 & 72 & 143 \\
Marsh Tit Entita & 409 & 560 & 679 & 525 \\
\hline
\end{tabular}

Table 3. Mean number of ringed nestlings per brood in different decades. Bold indicates average brood size statistically significantly different from the other brood sizes. s.e. $=$ standard error.

Medeltalet ringmärkta ungar per kull under olika årtionden. Fetstil indikerar kullstorlekar som statistiskt skiljer sig från övriga kullstorlekar. s.e. $=$ standardfel.

\begin{tabular}{lccccc}
\hline & \multicolumn{5}{c}{ Brood size (s.e.) Kullstorlek (s.e.) } \\
\cline { 2 - 5 } & $1962-1971$ & $1972-1981$ & $1982-1991$ & $1992-2001$ & $\mathrm{P}$ \\
\hline Coal Tit Svartmes & $7.52(0.087)$ & $7.58(0.065)$ & $\mathbf{7 . 8 0}(0.053)$ & $\mathbf{7 . 8 9}(0.062)$ & $<0.001$ \\
Crested Tit Tofsmes & $4.26(0.103)$ & $4.38(0.077)$ & $4.24(0.154)$ & $4.32(0.194)$ & 0.764 \\
Willow Tit Talltita & $6.86(0.189)$ & $6.50(0.116)$ & $6.58(0.220)$ & $6.92(0.156)$ & 0.116 \\
Marsh Tit Entita & $6.80(0.094)$ & $6.86(0.080)$ & $7.04(0.073)$ & $\mathbf{7 . 4 2}(0.083)$ & $<0.001$ \\
\hline
\end{tabular}

Table 4. Regression analysis of mean brood size in different years.

Regressionsanalys för medelkullstorlek under olika år.

\begin{tabular}{|c|c|c|c|}
\hline \multicolumn{3}{|c|}{$\begin{array}{l}\text { Regression coefficient } \\
\text { Regressionskoefficient }\end{array}$} & $\mathrm{P}$ \\
\hline Coal Tit Svartmes & $0.0118 *$ & 2.70 & 0.010 \\
\hline Crested Tit Tofsmes & -0.004 & -0.63 & 0.532 \\
\hline Willow Tit Talltita & 0.0059 & 0.5 & 0.620 \\
\hline Marsh Tit Entita & $0.017 *$ & 2.75 & 0.009 \\
\hline
\end{tabular}

*significant values signifikanta värden are still included in this study as a member of the brood. Nestlings that were ringed outside the nest, without any information regarding their original brood, were excluded from the present study.

A linear regression analysis was performed on the average brood size over time. For additional analyses the ringing data was divided into time periods, i.e. the four decades: 1962-1971, 19721981, 1982-1991 and 1992-2001. In order to investigate if there were any differences in brood sizes in different parts of the country, Sweden was divided into three regions: south (south of $59^{\circ} \mathrm{N}$ ), middle $\left(59^{\circ} \mathrm{N}-62^{\circ} \mathrm{N}\right)$ and north (north of $\left.62^{\circ} \mathrm{N}\right)$. Since all birds included in the study were ringed as nestlings, ringing date was used to test if the breeding start changed over the studied years. 
All statistical analyses were performed with JMP (version 2, SAS Institute Inc.). Mean group differences were tested with ANOVAs and Tukey-Kramer HSD. Changes in mean brood size between years were tested with linear regressions.

\section{Results}

\section{Number of broods ringed}

The number of broods ringed varied between species from 425 broods of Crested Tits to 3279 broods of Coal Tits (Table 1). The number of ringed broods also varied over time, but with only the Crested Tit showing a significant decrease over the last two decades $(b=-0.43, t=-3.95, P=0.0003$; Table 2$)$.

\section{Changes in brood sizes over time}

The average brood size for the whole time period varied from 4.32 (s.e. $=0.055$, Crested Tit) to 7.74 (s.e. $=0.032$, Coal Tit, Table 1). The average brood size increased over the studied time period in the Coal Tit and the Marsh Tit (Table 3), whereas no significant change could be detected for the Willow Tit and the Crested Tit. The Marsh Tit had largest brood sizes during the last decade and a regression analysis confirms a statistically significant increase over time $(b=+0.017, P=0.009$; Table 4$)$. This in- crease in brood size was paralleled by the Coal Tit which showed a statistically significant increase in brood size during the last two decades (1982-1991 and 1992-2001; Table 3). Regression analysis confirmed this increase $(b=+0.0118, P=0.010$; Table $4)$. The Crested Tit, which had a stable population over the monitored period (Lindström \& Svensson 2007), did not show any tendency towards changes in brood size, neither did the Willow Tit (Table 4).

\section{Differences in brood size between regions in Sweden}

Regional differences in brood size were recorded only for the Marsh Tit (Table 5). In the south region the Marsh Tit had larger brood sizes (on average 7.21 , s.e. $=0.048$, nestlings per brood) compared to the middle region (average 6.60, s.e. $=0.079$, nestlings per brood, $\mathrm{P}<0.001)$. Given the southern distribution of Marsh Tits, the number of ringed broods in the northern region was too small for this region to be included in the comparison.

\section{Unhatched eggs and dead nestlings}

The number of unhatched eggs was regularly reported only for the last two decades (1982-1991 and 1992-2001). A comparison between these

Table 5. Mean number of ringed nestlings per brood with standard error (s.e.) and number of ringed broods (N) in different regions of Sweden: South (south of $\left.59^{\circ} \mathrm{N}\right)$, Middle $\left(59^{\circ} \mathrm{N}-62^{\circ} \mathrm{N}\right)$ and North (north of $\left.62^{\circ} \mathrm{N}\right)$. The only significant difference is between South and Middle in Marsh Tit (ANOVA and Tukey-Kramer HSD*). Medeltalet ringmärkta ungar per kull (Mean), standardfel (s.e.) och antalet märkta kullar(N) i olika regioner $i$ Sverige: Södra $\left(\right.$ söder om $\left.59^{\circ} \mathrm{N}\right)$, Mellan $\left(59^{\circ} \mathrm{N}-62^{\circ} \mathrm{N}\right)$ och Norra $\left(\right.$ norr om $\left.62^{\circ} \mathrm{N}\right)$. Enda signifikanta skillnaden var mellan Södra och Mellan för entita (ANOVA och Tukey-Kramer HSD*).

\begin{tabular}{|c|c|c|c|c|c|c|c|c|c|c|c|}
\hline & \multicolumn{3}{|c|}{ South Södra } & \multicolumn{3}{|c|}{ Middle Mellan } & \multicolumn{3}{|c|}{ North Norra } & \multirow[t]{2}{*}{$\mathrm{P}$} & \multirow{2}{*}{$\begin{array}{c}\mathrm{N} \\
\text { total }\end{array}$} \\
\hline & Mean & s.e. & $\mathrm{N}$ & Mean & s.e. & $\mathrm{N}$ & Mean & s.e. & $\mathrm{N}$ & & \\
\hline Coal Tit Svartmes & 7.76 & 0.045 & 1651 & 7.70 & 0.049 & 1418 & 7.72 & 0.127 & 210 & 0.653 & 3279 \\
\hline Crested Tit Tofsmes & 4.25 & 0.080 & 201 & 4.39 & 0.078 & 212 & 4.25 & 0.327 & 12 & 0.734 & 425 \\
\hline Willow Tit Talltita & 6.53 & 0.106 & 309 & 6.83 & 0.140 & 178 & 6.88 & 0.206 & 82 & 0.136 & 569 \\
\hline Marsh Tit Entita & 7.21 & 0.048 & 1503 & 6.60 & 0.079 & 578 & 6.67 & 0.548 & 12 & $<0.001$ & 2093 \\
\hline
\end{tabular}

Table 6. The mean number of unhatched eggs and dead nestlings during 1982-1991 and 1992-2001. Sample size in parentheses.

Medelantalet rötägg och döda ungar under årtiondena 1982-1991 och 1992-2001. Antal kullar inom parentes.

\begin{tabular}{lcccccccc}
\hline & \multicolumn{3}{c}{ Unhatched eggs Rötägg } & & \multicolumn{3}{c}{ Dead young Döda ungar } \\
\cline { 2 - 4 } \cline { 7 - 9 } & $1982-1991$ & $1992-2001$ & $\mathrm{P}$ & & $1982-1991$ & $1992-2001$ & $\mathrm{P}$ \\
\hline Coal Tit Svartmes & $0.29(1124)$ & $0.24(833)$ & n.s & & $0.05(1126)$ & $0.05(836)$ & n.s. \\
Crested Tit Tofsmes & $0.38(53)$ & $0.18(33)$ & n.s & & 0 & 0 & \\
Willow Tit Talltita & $0.63(62)$ & $0.17(62)$ & 0.014 & & $0.24(143)$ & $0.17(143)$ & n.s \\
Marsh Tit Entita & $0.27(626)$ & $0.08(626)$ & n.s. & & $0.27(495)$ & $0.07(495)$ & n.s \\
\hline
\end{tabular}


two decades reveal that the Willow Tit showed significantly fewer unhatched eggs during the last decade (0.63 during 1982-1991 and 0.24 during 1992-2001, $\mathrm{P}=0.014)$. For the other species, no such differences were found (Table 6). The average number of unhatched eggs varied from 0.18 (Crested Tit 1992-2001) to 0.63 (Willow Tit 1982-1991).

The number of dead nestlings varied from on average 0 for the Crested Tit to 0.17 for the Willow Tit and showed no tendencies to change during the studied time period for either of the studied species.

\section{Timing of breeding}

The timing of breeding, as measured by ringing date, seemed to differ between the species with most broods of Crested Tits being ringed in May, whereas the majority of broods of the other three species were ringed in June (Table 7). The proportion of broods ringed in different months changed over the studied time period for the Crested Tit from $61 \%$ of the broods examined in May during 1962-1971 to $97 \%$ during 1992-2001 (Table 8). Marsh Tits showed the same pattern of earlier breeding over time, with the peak of breeding changing from June to May. Coal Tits showed a weak tendency to breed earlier, whereas the Willow Tits did not change timing of their breeding over the studied time period (Table 8).

\section{Discussion}

Three of the studied species of titmice have decreasing populations in Sweden, whereas the fourth, the Crested Tit, has a stable population. Interestingly, neither changes in brood size nor in number of dead nestlings or unhatched eggs, seem to co-vary with these patterns, and hence, the explanation to the declining populations has to be sought elsewhere. One possible explanation might be changes in adult or juvenile survival but

Table 7. The proportion (\%) of broods ringed in different months.

Andelen (\%) ringmärkta kullar per månad.

\begin{tabular}{lcccc}
\hline & May & Jun & Jul & Aug \\
\hline Coal Tit Svartmes & 28 & 61 & 11 & $<1$ \\
Crested Tit Tofsmes & 74 & 25 & 1 & 0 \\
Willow Tit Talltita & 5 & 90 & 4 & $<1$ \\
Marsh Tit Entita & 35 & 64 & 1 & 0 \\
\hline
\end{tabular}

Table 8 . The proportion (\%) of broods ringed per decade and month.

Andelen (\%) ringmärkta kullar per årtionde och månad.

\begin{tabular}{lcccc}
\hline & May & Jun & Jul & Aug \\
\hline Coal Tit Svartmes & & & & \\
1962-1971 & 13 & 72 & 15 & 0 \\
$1972-1981$ & 23 & 63 & 14 & 0 \\
$1982-1991$ & 33 & 58 & 9 & $<1$ \\
1992-2001 & 32 & 57 & 10 & $<1$ \\
Crested Tit Tofsmes & & & & \\
1962-1971 & 61 & 39 & 0 & 0 \\
$1972-1981$ & 79 & 20 & 1 & 0 \\
1982-1991 & 72 & 26 & 2 & 0 \\
1992-2001 & 97 & 3 & 0 & 0 \\
Willow Tit Talltita & & & & \\
$1962-1971$ & 5 & 92 & 3 & 0 \\
1972-1981 & 4 & 89 & 7 & $<1$ \\
$1982-1991$ & 10 & 89 & 1 & 0 \\
$1992-2001$ & 4 & 93 & 2 & 1 \\
Marsh Tit Entita & & & & \\
1962-1971 & 11 & 87 & 2 & 0 \\
$1972-1981$ & 26 & 73 & 1 & 0 \\
1982-1991 & 39 & 61 & $<1$ & 0 \\
1992-2001 & 59 & 41 & $<1$ & 0 \\
\hline
\end{tabular}

this does unfortunately go beyond the scope of the present study.

This study showed increasing brood sizes for decreasing populations of two titmice species and stable brood size for the third decreasing species. This pattern could possibly be explained by decreased competition, if the remaining individuals in the declining populations face relaxed competition with conspecifics and therefore might breed in territories of higher quality. Similar phenomenon have also been found in a few cases for species breeding in agricultural areas (Wheatear, Linnet, Starling; Ryttman \& Hall-Karlsson 2009) as well as for Wrynecks (Ryttman 2003).

The four titmice species investigated all have similar habits, prefer similar habitats and are of a similar size (Cramp 1989, Svensson m.fl. 1999). They are also all more or less sedentary (Fransson \& Hall-Karlsson 2008). They do however differ slightly in their breeding ecology and especially in their use on rotten tree trunks for breeding. Rotten tree trunks in forests have declined rapidly in Sweden and this has been linked to declining populations of forest birds (Carlsson \& Stenberg 1995). The Willow Tit is dependent of rotten trunks for digging out the nest holes. The Coal Tit and the Marsh Tit, on the other hand, use secondary holes 
from woodpeckers or nest boxes when provided. The decreasing numbers of rotten tree trunks in forests can therefore not explain the declining population of Coal Tits and Marsh Tits. One habit does however single out the Crested Tit from the other three species, and this is the high proportion of broods ringed in May compared to later months (Table 7). The majority of the broods of Marsh, Coal and Willow Tits were ringed in June, whereas as many as $74 \%$ of the Crested Tit broods were ringed in May. The proportion of Crested Tit broods ringed in May increased during the studied time period (Table 8) to the extent that almost no broods at all were ringed from June onwards during the last investigated decade. Marsh Tits and Coal Tits showed similar tendencies, but not to the same extent. Even though ringing of nestlings is performed on similar sized (aged) nestlings, one should bear in mind that the nestlings can be ringed during a time period of approximately 10 days, potentially inducing some variation in the estimation of the breeding start data. This is however not likely to be a problem since this variation is similar for all species.

Considering the recent climate change and the earlier onset of spring, breeding earlier might be crucial to ensure a successful breeding. Thessing (2000) showed that Willow Tits synchronise breeding to optimal food abundance for the chicks. Furthermore, warmer springs have been shown to lead to mistimed reproduction in Great Tits (Visser et al. 1998). If spring arrives earlier every year, as is nowadays well recorded (c.f. Hüppop \& Hüppop 2003), it is possible that this synchronisation does not work as well as before. This mismatched breeding could then potentially affect both adults and juveniles negatively. The Crested Tits, with the increasing habit of early breeding, might have adapted to the earlier availability of larvae and consequently hatch their eggs at a time period with high food abundance. Crested Tits might therefore be more successful and have more offspring surviving to breeding age compared to Willow Tits, Marsh Tits and Coal Tits.

In this study we have shown that decreasing populations of titmice show increasing brood sizes. Furthermore we show that the decrease in population size cannot be explained by any changes in the number of dead nestlings, or the number of unhatched eggs. We have also shown that the species with a stable population size (Crested Tit) is the species with the most pronounced habit of early breeding. We suggest that the decreasing populations may be a result of decreasing survival of juvenile birds to breeding age or a decreasing survival of adult birds.

\section{Acknowledgements}

We thank the personnel at the Swedish Bird Ringing Center (Swedish Museum of Natural History) for very kind treatment and support at our work with all the files with ringing data. We also thank an anonymous referee for valuable suggestions for a better manuscript.

\section{References}

Carlsson, A. \& Stenberg, I. 1995. Vitryggig hackspett (Dendrocopos leucotos). Biotopval och sårbarhetsanalys. Rapport 27, Sveriges Lantbruksuniversitet, Uppsala.

Cramp, S. (ed.) 1989. Handbook of the birds of Europe, the Middle East and North Africa. The birds of Western Palearctic. Vol. VI. Oxford Univ. Press, Oxford.

Fransson, T. \& Hall-Karlsson, S. 2008. Svensk ringmärkningsatlas. Vol. 3, Stockholm. (Swedish Bird Ringing Atlas, Vol. 3. Stockholm).

Hüppop, O. \& Hüppop, K. 2003. North Atlantic Oscillation and timing of spring migration in birds. Proc. R. Soc. Lond. B. 270: 233-240.

Lindström, Å. \& Svensson, S. 2003. Övervakning av fåglarnas populationsutveckling och starens häckningsframgång. Arsrapport för 2002. (Monitoring population changes of birds in Sweden and breeding success of the Starling. Annual report for 2002). Department of Ecology, Lund University, $88 \mathrm{pp}$.

Lindström, Å. \& Svensson, S. 2007. Övervakning av fåglarnas populationsutveckling. Arsrapport för 2006. (Monitoring population changes of birds in Sweden. Annual report for 2006). Department of Ecology, Lund University, 66 pp.

Ryttman, H. \& Hall-Karlsson, K.S.S. 2009. Brood size of twelve species connected to farmlands during 1962-2001. (Kullstorlek hos tolv jordbruksfåglar under perioden 1962-2001). Ornis Svecia 19: 3-12.

Ryttman, H. 2003. Breeding success of Wryneck Jynx torquilla during the last 40 years in Sweden. Ornis Svecia 13(1): 25-28.

Svensson, S., Svensson, M. \& Tjernberg, M. 1999. Svensk fågelatlas. Vår fågelvärld, supplement 31, Stockholm.

Thessing. A. 2000. Growth and final size of Willow Tit $P a$ rus montanus under different environmental conditions. Ardea 88 (2): 215-224.

Visser, M.E., van Noordwijk, A.J., Tinbergen, J.M., Lessells, C.M. (1998). Warmer springs lead to mistimed reproduction in great tits (Parus major). Proc. R. Soc. Lond. B 265, 1867-1870.

\section{Sammanfattning}

Vi har undersökt fyra mesars, svartmes Parus ater, talltita Parus montanus, entita Parus palustris och tofsmes Parus cristatus, häckningsframgång 
under åren 1962 till 2001 (Tabell 1 och 2). Som mått på häckningsframgången använde vi de ungkullstorlekar som rapporterats till ringmärkningscentralen i samband med ringmärkningen under perioden 1962-2001. Tre av arterna, talltita, entita och svartmes, visar minskande populationstrender i Sverige under denna period. För svartmesen tycks nedgången ha börjat på 1990-talet (Lindström \& Svensson 2007). Tofsmesen tycks däremot ha en stabil population.

Vi fann att två av de tre minskande mespopulationerna (entita och svartmes) hade sina största kullstorlekar mellan 1992 och 2001 (Tabell 3) och dessa båda arter visar också en statistiskt signifikant tendens för ökande kullstorlek under de undersökta åren (Tabell 4). Talltitan och tofsmesen visade ingen förändring i kullstorlek under de studerade åren. De nedåtgående populationstrenderna i Sverige tycks alltså inte bero på minskande kullstorlekar. Vi hittade bara små skillnader mellan olika delar av landet och enda signifikanta skillnaden var att entitan hade större kullar i södra än i mellersta Sverige (Tabell 5).

De större kullstorlekarna som svartmes och entita visar kan bero på minskad konkurrens mellan de kvarvarande individerna om de bästa reviren. Fler goda revir finns att tillgå då färre individer finns kvar i populationen och $\mathrm{i}$ ett bättre revir kan fler ungar födas upp.

Talltitan hade signifikant lägre antal rötägg under 1992-2001 jämfört med 1982-1991 medan det för övriga tre arter inte fanns någon tendens till vare sig ökning eller minskning i antalet rötägg. Antal döda ungar per kull varierade mellan 0 för tofsmes och 0,17 för talltita, men ingen av arterna visade någon tendens till förändring av denna andel över tiden. Kort sagt indikerar vår studie att varken förändringar i kullstorlek, antalet döda ungar eller antalet rötägg kan förklara de minskande populationerna hos tre av skogsmesarna (Tabell 6).

De fyra undersökta arterna har mycket lika vanor, föredrar mycket lika habitat, är ungefär lika stora samt är mer eller mindre lika stationära. Tofsmesen skiljer ut sig från de övriga arterna genom att lägga majoriteten av sina kullar i maj, medan övriga arter lägger majoriteten av kullarna i juni (Tabell 7). Under den tidsperiod som har undersökts har tofsmesen förändrat sina häckningsvanor så att en allt större andel av kullarna läggs tidigt på säsongen (Tabell 8). Entitan och svartmesen visar liknande tendenser men inte lika extremt som tofsmesen. Thessing (2000) visade att talltitan synkroniserar sin häckning med den optimala tiden för mat till ungarna. I och med klimatförändringarna har nu våren börjat infalla allt tidigare på året och det är då möjligt att denna synkronisering fungerar allt sämre. Att lägga allt tidigare kullar skulle kunna leda till en högre överlevnad för tofsmesens ungar eftersom de kläcks under en period när födotillgången fortfarande är tillräckligt god. Det är möjligt att detta är förklaringen till att tofsmesen är den av de fyra undersökta arterna som inte minskar i antal. 